\title{
Average Harvesting Charges for Florida Citrus, 2002-20031
}

Ronald P. Muraro ${ }^{2}$

A survey was conducted in Spring of 2003 to collect Florida citrus harvesting charges (picking, roadsiding, and hauling). Harvesting charges for the 2002-2003 season were collected for both fresh and processed market citrus fruit. The survey was not a statistically chosen sample; therefore, the charges may not represent Florida's total citrus industry. The participants were chosen because of their willingness to provide their harvesting charges. The survey will continue as long as there is adequate participation.

The harvesting charges provided by the participating firms came from either their own citrus harvesting division or from other commercial harvesting firms. The harvested citrus varieties include early and late oranges, red and white grapefruit, temples/tangelos and tangerines. All charges were reported in "Florida field box" units, with a Florida field box equaling the following weight equivalents: oranges $=90$ pounds, grapefruit $=$ 85 pounds, and tangerines $=95$ pounds .

The harvesting charges were summarized into three categories:

1. Picking represents the cost paid to the person picking or removing the fruit from the tree.
2. Roadsiding represents the costs the harvester incurs to transport the "picked" fruit to the transport flatbed truck or trailer. Also included in these charges are the costs for fruit containers (e.g., pallets, boxes, and tubs), ladders and worker transport equipment, and payroll taxes insurance (e.g., workers' compensation and liability).

3. Hauling represents the costs associated with transporting the fruit to either the fresh fruit packinghouse or juice processing plant.

The 2002-2003 average harvesting charges for Florida citrus (fresh and processed market citrus) are presented in Table 1 for both range and overall average. The picking and roadsiding charges for fresh fruit were higher than for processed fruit. However, no distinction was reported for hauling charges between fresh and processed citrus.

Additional information on citrus budgeting and cost analysis and harvesting charges (picking, roadsiding, and hauling) can be obtained by contacting your County Extension Citrus Agent or by going to the UF/IFAS Citrus Research and Education Center website at http://lal.ufl.edu.

1. This is EDIS document FE435, a publication of the Department of Food and Resource Economics, Florida Cooperative Extension Service, UF/IFAS, University of Florida, Gainesville, FL. Published October 2004. Please visit the EDIS website at http://edis.ifas.ufl.edu.

2. Ronald P. Muraro, Professor, Department of Food and Resource Economics, Citrus Research and Education Center, Lake Alfred, FL, Florida Cooperative Extension Service, UF/IFAS, University of Florida, Gainesville, FL.

The Institute of Food and Agricultural Sciences is an equal opportunity/affirmative action employer authorized to provide research, educational information and other services only to individuals and institutions that function without regard to race, color, sex, age, handicap, or national origin. For information on obtaining other extension publications, contact your county Cooperative Extension Service office. Florida Cooperative Extension Service/Institute of Food and Agricultural Sciences/University of Florida/Christine Taylor Waddill, Dean. 
Table 1. Estimated average harvesting charges for Florida, 2002-2003.

\begin{tabular}{|c|c|c|c|c|}
\hline \multirow[t]{2}{*}{ Picking Charges } & \multicolumn{2}{|c|}{ Fresh Fruit } & \multicolumn{2}{|c|}{ Processed Fruit } \\
\hline & Range & Average & Range & Average \\
\hline & \multicolumn{2}{|c|}{ dollar/box } & \multicolumn{2}{|c|}{ dollar/box } \\
\hline Early \& Mid-Season Oranges & $0.72-0.90$ & 0.814 & $0.75-0.90$ & 0.806 \\
\hline Valencia Oranges & $0.79-0.90$ & 0.835 & $0.76-0.90$ & 0.810 \\
\hline Pink/Red Grapefruit & $0.60-0.80$ & 0.692 & $0.55-0.75$ & 0.625 \\
\hline White/Marsh Grapefruit & $0.60-0.77$ & 0.668 & $0.50-0.75$ & 0.600 \\
\hline Temples \& Tangelos & $0.85-0.90$ & 0.883 & $0.85-0.90$ & 0.860 \\
\hline Tangerines & $1.35-1.91$ & 1.600 & - & - \\
\hline \multirow[t]{2}{*}{ Roadsiding Charges } & \multicolumn{2}{|c|}{ Fresh Fruit } & \multicolumn{2}{|c|}{ Processed Fruit } \\
\hline & Range & Average & Range & Average \\
\hline & \multicolumn{2}{|c|}{ dollar/box } & \multicolumn{2}{|c|}{ dollar/box } \\
\hline Early \& Mid-Season Oranges & $0.75-1.03$ & 0.882 & $0.70-0.96$ & 0.838 \\
\hline Valencia Oranges & $0.75-1.08$ & 0.910 & $0.70-0.96$ & 0.851 \\
\hline Pink/Red Grapefruit & $0.75-0.85$ & 0.792 & $0.75-0.77$ & 0.758 \\
\hline White/Marsh Grapefruit & $0.75-0.81$ & 0.778 & $0.75-0.77$ & 0.758 \\
\hline Temples \& Tangelos & $0.90-0.95$ & 0.927 & $0.76-0.90$ & 0.850 \\
\hline Tangerines & $1.12-1.21$ & 1.177 & - & - \\
\hline \multirow[t]{2}{*}{ Hauling Charges } & \multicolumn{2}{|c|}{ Fresh Fruit } & \multicolumn{2}{|c|}{ Processed Fruit } \\
\hline & \multicolumn{2}{|c|}{ All Varieties } & \multicolumn{2}{|c|}{ All Varieties } \\
\hline & \multicolumn{2}{|c|}{ dollar/box } & \multicolumn{2}{|c|}{ dollar/box } \\
\hline $0-30$ miles & \multicolumn{2}{|c|}{0.408} & \multicolumn{2}{|c|}{0.384} \\
\hline $31-50$ miles & \multicolumn{2}{|c|}{0.445} & \multicolumn{2}{|c|}{0.433} \\
\hline $51-80$ miles & \multicolumn{2}{|c|}{0.517} & \multicolumn{2}{|c|}{0.498} \\
\hline $81-100$ miles & \multicolumn{2}{|c|}{0.575} & \multicolumn{2}{|c|}{0.551} \\
\hline $100+$ miles & \multicolumn{2}{|c|}{0.663} & \multicolumn{2}{|c|}{0.625} \\
\hline
\end{tabular}

